\author{
Citation: Şener S. \& Ballı E., The Effect Of Organizational Climate On The Affective \\ Commitment And Job Satisfaction, BMIJ, (2020), 8(3): 3302-3327, doi: \\ http://dx.doi.org/10.15295/bmij.v8i3.1599
}

\title{
THE EFFECT OF ORGANISATIONAL CLIMATE ON THE AFFECTIVE COMMITMENT AND JOB SATISFACTION¹
}

\author{
Süreyya ŞENER 2 \\ Erdinç BALLI ${ }^{3}$
}

\author{
Received Date (Başvuru Tarihi): \\ Accepted Date (Kabul Tarihi): \\ Published Date (Yayın Tarihi):
}

$20 / 08 / 2020$

$15 / 09 / 2020$

$25 / 09 / 2020$

In the article, the first author is in the role of the Corresponding Author.

\section{ABSTRACT}

Keywords:

Organisational Climate,

Affective Commitment,

Job Satisfaction,

Hotel Employees

JEL Codes:

M10,

Z31
Organisational climate is expressed as the atmosphere/mood perceived indirectly or directly by the employees of the organisation. Organisational climate may be useful on several organisational variables, especially the behaviours and attitudes of the employees within the organisation. In this study, the organisational climate's effect on affective commitment and job satisfaction was investigated. The data were collected with a survey applied to 362 employees who were working in 4 or 5-star hotel enterprises in Adana and Mersin. Consequently, it was discovered that there is a significant positive relationship between the organisational climate, affective commitment $(r=0,661 ; p<0.001)$ and job satisfaction $(r=0,766 ; p<0.001)$ of the employees, and that the organisational climate affects the organisational commitment $\left(R^{2}=0,455\right)$ and job satisfaction $\left(R^{2}=0,596\right)$ levels of the employees in a positive way. Moreover, as a result of the multilinear regression analyses, the dimensions of organisational structure, rewarding, work environment and support, which are among the sub-dimensions of the organisational climate, were seen to play a role in the affective commitment and job satisfaction of the employees.

\section{ÖRGÜT İKLIMININ, DUYGUSAL BAĞLILIK VE İs TATMININE ETKİSİ}

$\ddot{O} Z$

\section{Anahtar Kelimeler:}

Örgüt İklimi,

Duygusal Bağglılı,

Iş Tatmini,

Otel Çalışanları

\section{JEL Kodlar:}

M10,

Z31
Örgüt iklimi; örgüt çalışanları tarafindan dolaylı ya da dolaysız algılan atmosfer/hava olarak ifade edilmektedir. Örgüt iklimi başta çalışanların örgüt içindeki davranış ve tutumları olmak üzere birçok örgütsel değişken üzerinde etkili olabilmektedir. Bu çalışmada örgüt ikliminin, çalışanların duygusal bağhlklarn ve iş tatminlerine etkisi incelenmiştir. Veriler, Adana ve Mersin illerinde faaliyet gösteren 4 ve 5 yıldızh otel işletmelerinde çalışan 362 kişiye uygulanan anket ile toplanmıştır. Yapılan korelasyon analizleri sonucunda; çalışanların örgüt iklimi algıları ile duygusal bağhllı ( $r=, 661$; $p<0.001)$ ve iş tatminleri $(r=, 766 ; p<0.001)$ arasında anlamlı pozitif bir ilişki olduğu ve örgüt ikliminin çalışanların örgütsel bağhllı $\left(R^{2}=0,663\right)$ ve iş tatmini $\left(R^{2}=0,603\right)$ düzeylerini pozitif yönde etkilediği saptanmıştır. Ayrıca yapılan çoklu doğrusal regresyon analizleri sonucunda; örgüt ikliminin alt boyutlarından organizasyon yapısı, ödül, çalışma ortamı ve destek boyutlarının çalışanların duygusal bağlılıkları ve organizasyon yapısı, ödül, çalışma ortamı ve destek boyutlarının da iş tatminleri üzerinde pozitif etkileri olduğu görülmüş̧ür.

\footnotetext{
${ }^{1}$ This article was produced from master's thesis titled "Investigation Of Organizational Climate's Effect On Organizational Commitment And Job Satisfaction Of Employees: Example Of Adana-Mersin Hotel Enterprises".

${ }^{2}$ Msc, Cag University, Institute of Social Sciences, senersureyya@gmail.com, https://orcid.org/0000-0001-9946-8356

${ }^{3}$ Asst. Prof. Dr., Cukurova University, Tourism and Hotel Management, eballi@cu.edu.tr, https://orcid.org/0000-0001-5111-1868
} 


\section{INTRODUCTION}

Employees in accommodation enterprises are the ones who produce the product by using other means of production. While creating a product, they reflect their knowledge and skills to their work. As a result of this reflection, the more successful they are in their work, the more they contribute to reaching the goals of their organisations. In general, the production and consumption of products are synchronous in hotel businesses. Since employees and customers are in face-to-face communication, the role of employees in the quality of the product and customer satisfaction is more significant than in other sectors. Therefore, the factor of the employee in accommodation enterprises is directly related to the organisation's success and survival. In this sense, it is also possible to say that the success of the employee is the success of the organisation. However, it is not enough for employees to make an effort and have the necessary knowledge and skills to perform their job well and be successful in the organisation. It is equally effective that they are wellmotivated and identified themselves with their organisation and its goals and satisfied with their job.

When the relevant literature and working life are examined, it is seen that in hotel enterprises, employees' commitment to the organisation and their job satisfaction are one of the main factors that affect their performance and success. The strengthening and growth of organisations depend on the intense feelings of the employees towards their organisations. To achieve this, as well as the knowledge and skills required by the job (Bolat and Bolat, 2008), employees should have positive feelings and commitment to their organisations, and they should be satisfied with their jobs. The more employees have positive feelings towards their organisations and job, and the more they feel attached to the organisation and satisfy with their job, the more successful they are in their duties and contribute to the organisation. Otherwise, employees may be unable to meet the expectations, and they may work inefficiently, move away from that organisation and fail at any moment, and this situation may reflect negatively on the success of the organisation. In this sense, one of the top conditions for the organisation to continue a successful activity is that the human power resource, which is accepted as the most crucial source of 
organisational life, loves, adopts and attaches to its organisation (Güney, 2012: 281282). Besides, when looking at the studies examining the results of these two concepts, it is observed that the concepts are in a negative relationship with many behaviours that are not desired to be seen in the organisation, while they have a positive relationship with the desired ones (Mowday, Porter and Steers, 1982: 137). For this reason, it is essential to examine these concepts and the variables that can affect them in terms of organisational success.

Organisational climate is one of the most critical organisational variables that are thought to be directly or indirectly effective in many other attitudes and behaviours of employees, such as affective commitment and job satisfaction. Because of being a concept that reflects employee perception, organisational climate is generally thought as directly related to employee psychology. Organisational climate can be useful on many organisational variables, especially the behaviour and attitudes of employees within the organisation. Due to its effects in organisational life, it affects different situations directly or indirectly; therefore, it becomes crucial in many ways. Studies show that while organisational climate has a positive effect on organisational efficiency and productivity (Pritchard and Karasick, 1973), creativity (Amabile, Conti, Coon, Lazenby and Herron, 1996; Shalley, Gilson, and Blum, 2000; Çekmecelioğlu, 2006), and affective labour, it harms behaviours such as mobbing (Mercan, 2007), burnout (Zeybek, 2010) and intention to quit (Pritchard and Karasick, 1973; Schnedder and Snyder, 1975).

In this study, the relationships between organisational climate, affective organisational commitment and job satisfaction, which are essential concepts for organisational life, are examined. In addition, the effect of the organisational climate on the employees' job satisfaction and organisational commitment is investigated in hotel enterprises, which is an important branch of the tourism sector.

\section{LITERATURE REVIEW AND HYPOTHESES}

In this section, organisational climate, as the independent variable, and the necessary information about affective organisational commitment and job satisfaction, as the dependent variables, are briefly mentioned, and the hypotheses 
and previous studies based on the relationships between these variables are included.

\subsection{Affective Commitment}

Organisational commitment means that employees believe in the goals and values of the organisation, are willing to stay in the organisation and make an effort to reach the organisation's goals (Mowday, Porter, and Steers, 1979: 231). Organisational commitment can also be considered as the degree to which employees feel loyal to their organisation and to identify and deal with the organisation they work for (Köse, Kartal, and Kayalı, 2003). Employees' commitment to their organisations includes three essential elements: wholehearted acceptance and support of the organisation's goals and mission, willingness to sacrifice to achieve the organisation's mission and goals, and the need to remain a member of the organisation (Porter, Steers, Mowday and Boulian, 1974). Allen and Meyer (1990) also argue that organisational commitment is based on three main elements as an affective, continuance and normative commitment. The affective commitment of employees refers to the situation in which they integrate and identify themselves with their organisation. Continuance commitment, also known as rational commitment, means being aware of the costs of leaving the organisation. The commitment that emerges as a result of the employee's seeing commitment to his/her organisation as a duty and thinking that his/her commitment to the organisation and his/her colleagues is correct expresses normative commitment.

Affective commitment, which is a sincere and voluntary type of commitment that employees develop by identifying themselves with their organisation, is the type of commitment that organisations want to see most since employees with high affective commitment stay in the organisation because they want to. They make great efforts for the interests of the organisation (Uyguç and Çımrın, 2004). According to Allen and Meyer (1990), affective commitment reflects the strength of the employee to identify him/herself with the organisation, for Mathieu and Zajac (1990), it is an essential indicator of integration with the job. Employees who have developed affective commitment are employees who devote themselves to the organisation and 
have a sense of loyalty (Ada, Alver and Atl1, 2008). In order to achieve practical commitment, employees must accept and integrate with organisational values. This integration enables the employee to see him/herself as a part of the organisation and to voluntarily contribute to reaching the organisational goals (Yalçın and İplik, 2005). In short, the employees, who feel affective commitment, adopt and accept the organisational values, and as a result, they make more effort to be more beneficial to the organisation. Also, they generally do not intend to leave the organisation (Oktay and Gül, 2003: 407), since these employees are integrated with their organisations, and they are happy to be a part of the organisation (Uyguç and Çımrın, 2000: 91). Accordingly, affective commitment is the most desired type of commitment by organisations (Arslan, 2009, p.48). Allen and Meyer stated that the factors affecting sufficient commitment might be the difficulty of the job, the clarity of the roles and goals, the management approach open to suggestions, friendship relations and the management's fairness (Gündoğan, 2009).

\subsection{Job Satisfaction}

Job satisfaction is the positive emotional state reached by an employee as a result of evaluating his/her job or work life. Job satisfaction is a feeling towards the job when the values that an employee can obtain from the organisation are compatible with the values s/he needs (Başaran, 1992). Locke (1969) explains job satisfaction as the pleasurable emotional state that results from one is accomplishing his/her job or helping others to get the job done. Job satisfaction may be an internal satisfaction arising from situations such as the job itself, personal development, job performance or responsibility taken, as well as an external one arising from situations such as wages, company policies, senior management support or promotion opportunities. A high level of job satisfaction is desired by enterprises since it is seen as an indication that the organisation is managed well. Job dissatisfaction arises when an employee perceives that his/her job and job environment expectations are not met sufficiently. Job dissatisfaction causes the employee's workforce productivity to be negatively affected, his/her commitment to work to decrease, and the labour turnover rate to increase (Demir, Usta, and Okan, 2008: 154), therefore, it negatively affects the success of the enterprise. Job satisfaction 
can be influenced by personal factors such as gender, age, experience and educational status, as well as organisational factors such as wage, promotion, working conditions, and organizational factors.

\subsection{Organisational Climate}

Tagiuri (1968) stated that before defining the concept of organisational climate, the concept of climate should be explained first and defined it as a set of environmental features tested by those in the environment that affect their behaviour. Stringer (2002) discovered that climate could alter the members of the organisation and defined the concept of organisational climate as a collection of environmental factors, expectations and motives perceived directly or indirectly by the people around. Moran and Volkwein (1992), on the other hand, said that organisational climate is a framework that defines the work environment in any situation, shapes and affects work behaviour. Hemingway and Smith (1999) mentioned the importance of perceptions while defining organisational climate and defined it as the common perception of the employees about the organisational environment. In line with all these definitions and explanations, it can be said that the organisational climate is related to the practices and work environment felt by the employees or the dominant atmosphere within the organisation. It is the way through which the employees perceive this atmosphere reflected by the procedures in their workplace (Hocaniyazov, 2008).

Looking at the studies on organisational climate, it is seen that the organisational climate has been dimensioned in different ways by different researchers (Litwin and Stringer, 1968; Scheneider, 1996; Zammuto and Krackover, 1991). Within the scope of this study, the organisational climate dimensioning of Litwin and Stringer was taken as the basis and explained. The researchers gathered the organisational climate in measurable dimensions as organisational structure, rewarding, support, individual responsibility, moderate work environment and risktaking.

The organisational structure can be rigid or flexible. Inflexible organisations, business policies and organisational structure are not clearly defined, and job 
descriptions for employees are not specified. It is not clear who is the responsible person in the decision-making process. Besides, the distance between manager and employees is minimal. While rigid organisational structures cause an organisational climate that prevents empowerment and creativity, flexible organisational structure, that is, distribution of authority according to different statuses, increases empowerment and creativity (Keleş, 2008: 43). Knowing that employees are the owner of their job, the ability to take risks, and being aware of not only their job but also the operation around them are defined as individual responsibility (Şener, 2017, p.28). Individual responsibility is a condition related to the level of feeling that employees are personally responsible for their job (Atkinson and Frechete, 2009). Responsibility awareness will enable the employee to plan carefully before starting the work to be performed, to take precautions against any negativities that may occur later, and to undertake this in a negative situation. People with a high need to feel successful generally prefer jobs where they can take more individual responsibility. The perception gained as a result of the excellent performance of the work requested by the management constitutes the rewarding dimension of the climate (Yüceler, 2005: 47). As employees see that their efforts are appreciated and reciprocated, they become motivated and are interested in ambitious work (Özdemir, 2006, pp. 25-27).

For this reason, in order to ensure high productivity, it is vital to recognise and reward good performance. Risk-taking is the uncertainty tolerance that the organisation gives to the employee. Employees' ability to take risks is a critical issue determined or encouraged by the organisation (Şener, 2017). Exploration is thought to be at the root of the reasons that push employees to take risks. As a result of the researches, it can be said that an organisation that supports risk-taking will encourage its employees in this regard; therefore, it can increase productivity (Leonard and Swap, 2005). The moderate work environment is the dimension in which factors such as friendship, friendly atmosphere and warmth created within the organisation are perceived by employees (Şener, 2017, p.29). In organisations with a moderate work environment, a friendly atmosphere prevails among employees. There is a moderate and calm work environment; employees are not cold to each 
other and do not stay away. There is also a moderate relationship between employees and management. The Perception of Support is defined as a person's acceptance or approval by the other individuals within the organisation (Spreitzer, 1996). In organisations where the perception of support is felt, the management deals with the career expectations of the employees and supports them in case of mistakes. The employee believes that when s/he takes on a difficult task, s/he will receive support from his/her friends and management.

\subsection{Relationships Between Variables and Hypotheses}

Due to its effects in organisational life, organisational climate affects different situations directly or indirectly and therefore becomes essential in many ways. It is generally thought that the organisational climate is directly related to employee psychology because it is a concept that reflects the perception of employees. Improving the work environment of organisations and environmental factors affecting the work can also increase the productivity of the employees. Situations that reflect the organisational climate, such as organisational structure, management behaviour, organisational procedures, relationships with colleagues, work opportunities, physical conditions, can play a role in the employee's affections, motivations, and performances towards the organisation and work (Rusu and Avasilca, 2014).

When the relevant literature is examined, it is seen that there are studies that reveal the effect of organisational climate on organisational commitment. In their studies, Tyagi and Wotruba (1993), Özdevecioğlu (2003), Parker et al. (2003), Halis and Uğurlu (2008), Hughes, Avey and Norman (2008), Çekmecelioğlu (2011) and Dorgham (2012) stated that organisational climate plays a role on the employees' organisational commitment and affects it positively. The better the organisational climate is, the greater the organisational commitment is achieved (Clercq and Rius, 2007; Pati and Reilly, 1977; Ruth, 1992). It can also be said that positive changes in the organisational climate positively affect the organisational commitment of employees (Bas, Amarat et al., 2018; Hassan and Rohrbaugh, 2012). Researchers suggested that autonomy (Wallace, Hunt, and Richards, 1996) and administrative support (Benson, 
1996) are positively associated with organisational commitment. Also, Steers (1977) found a relationship between the autonomy and trust dimensions of the organisational climate and commitment. Çekmecelioğlu (2011), Riad, Labib and Nawar (2016) stated in their studies that the organisational climate positively affected the affective commitment of the employees.

Based on the relevant explanations and studies, the following hypotheses have been produced within the scope of the relationship between the organisational climate and the affective commitment of employees:

$\boldsymbol{H}_{1}$ : Organisational climate has a positive and significant effect on employees' affective commitment.

$H_{1 a}$ : Organisational structure dimension has a positive and significant effect on employees' affective commitment.

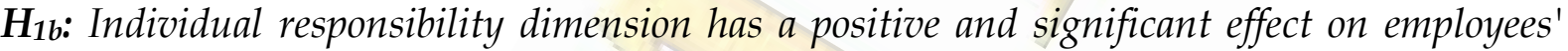
affective commitment.

$H_{1 c}$ : Rewarding dimension has a positive and significant effect on employees' affective commitment.

$\boldsymbol{H}_{1 d:}$ Risk-taking dimension has a positive and significant effect on employees' affective commitment.

$H_{1 e}$ : Work environment dimension has a positive and significant effect on employees' affective commitment.

$\boldsymbol{H}_{1 f}$. Support dimension has a positive and significant effect on employees' affective commitment.

Organisational climate is also positively associated with job satisfaction. With the high organisational climate, job satisfaction also increases (Pati and Reilly, 1977; Ruth, 1992; Clercq and Rius, 2007). Mahajan, Churchill, Ford and Walker (1984), Putti and Kheun (1986), Gratto (2001), Topçu (2006), Castro (2008), Özsoy (2012), Erdoğan (2013) and Sönmez (2014) demonstrated in their studies that organisational climate plays a role on employees' job satisfaction and affects it positively. 
Accordingly, the following hypotheses have been produced within the scope of the relationship between organisational climate and employees' job satisfaction:

$\mathbf{H}_{2}$ : Organisational climate has a positive and significant effect on employees' job satisfaction. $H_{2 a}$ : Organisational structure dimension has a positive and significant effect on employees' job satisfaction.

$\boldsymbol{H}_{2 b}$ : Individual responsibility dimension has a positive and significant effect on employees' job satisfaction.

$\boldsymbol{H}_{2 c}$ : Rewarding dimension has a positive and significant effect on employees' job satisfaction.

$\boldsymbol{H}_{2 d}$ : Risk-taking dimension has a positive and significant effect on employees' job satisfaction.

$\boldsymbol{H}_{2 e}$ : Work environment dimension has a positive and significant effect on employees' job satisfaction.

$\boldsymbol{H}_{2 f}$. Support dimension has a positive and significant effect on employees' job satisfaction.

\section{RESEARCH METHOD}

In this study, which examines the effect of organisational climate on the organisational commitment and job satisfaction in the hotel staff sample, a relational screening model was adopted. The data needed to achieve the determined purpose were collected by the survey method. The questionnaire form consists of four sections. In the first section, there is Stringer's (2002) "Organizational Climate Scale" consisting of 30 items and 6 dimensions which are organisational structure, individual responsibility, rewarding, risk-taking, moderate work environment and support. The validity and reliability of the scale in Turkish culture has been demonstrated in different studies (Gerçeker 2012; Akdemir 2017). In the second section, the affective commitment dimension consisting of 6 items of the "Organisational Commitment Scale" that consists 18 statements and 3 dimensions developed by Meyer and Allen (1991) and revised by Meyer, Allen and Smith (1993) was used. Adaptation of the scale to Turkish culture was made by Wasti (2000). In the third section, the "Job Satisfaction Scale", which consists of a single dimension and 9 items, developed by Bilir (2005) was used. In the last section, there are five demographic information questions. The response categories of the items in all three 
scales were subjected to a 5-point Likert rating. Response categories were scored as (1) strongly disagree, (2) disagree, (3) undecided, (4) agree, (5) strongly agree.

Employees in 4 and 5-star hotel enterprises operating in Adana and Mersin constitute the universe of this study. One of the reasons why 4 and 5-star hotels were chosen as the universe of the study is that these hotels are generally in the category of city hotels, so the personnel turnover rate in these enterprises is lower than seasonal hotel enterprises. In this sense, it was thought that the hotel staff within the scope of the research worked in their organisations for many years, knew and evaluated both their organisations and their organisational attitudes better. Therefore, within the scope of this research, it was thought that more realistic data could be collected about variables such as organisational climate, organisational commitment and job satisfaction, and more valid findings could be revealed by making balanced analyses with the data collected in this way. In addition, the fact that 4 and 5-star hotel enterprises have vast organisational opportunities in terms of management and organisational structures is another reason for being selected as the universe of the study. According to the Ministry of Culture and Tourism, there are 13 five star and 31 four-star hotels in Adana and Mersin provinces. In total, 5-star hotels have a bed capacity of 5142 and 4-star hotels as 5062. A ğaoğlu (1992) states that the rate of personnel per bed in 5-star hotel enterprises is 0.59, and in 4-star hotel enterprises, it is 0.38 . With this approach, it can be said that there are 4958 employees in total in enterprises. Yazıcıoğlu and Erdoğan (2004) state that in populations up to 5000 , at least 357 samples at an error rate of 0.05 can represent the universe. The research data were collected between April 2019 and June 2019 through face-to-face and web-based (online) surveys. At the end of the data collection process, 362 questionnaires, 114 of which are face-to-face and 248 of which are web-based, that can be used for analysis were obtained.

\section{FINDINGS}

\subsection{Demographic Characteristics of Participants}

When Table 1, which gives demographic information about the gender, age, education level, marital status and working period of 362 hotel employees, is 
investigated, it is seen that most of the participants are male $(n=242)$, single $(n=$ $245)$, between the ages of 26-35 $(n=165)$, have 1-5 years of experience $(n=173)$ and graduate-level of education $(n=151)$.

Table 1. Demographic Findings of the Participants

\begin{tabular}{|c|c|c|c|c|c|}
\hline Gender & $\bar{n}$ & $\%$ & Working Period & $\bar{n}$ & $\%$ \\
\hline Male & 242 & 66,9 & \multirow{5}{*}{$\begin{array}{l}\text { Less than } 1 \text { year } \\
1-5 \\
6-10 \\
11-20 \\
21+\end{array}$} & 66 & 18,2 \\
\hline Female & 120 & 33,1 & & 173 & 47,8 \\
\hline Education & $\bar{n}$ & $\%$ & & 77 & 21,3 \\
\hline Primary & 13 & 3,6 & & 34 & 9,4 \\
\hline High School & 107 & 29,6 & & 12 & 3,3 \\
\hline Associate & $\overline{72}$ & 19,9 & Age & $\bar{n}$ & $\%$ \\
\hline Undergraduate & 151 & 41,7 & $18-25$ & 113 & 31,2 \\
\hline Graduate & 19 & 5,2 & $26-35$ & 165 & 45,6 \\
\hline Marital Status & $\bar{n}$ & $\%$ & $36-45$ & 56 & 15,5 \\
\hline \multirow{2}{*}{$\begin{array}{l}\text { Single } \\
\text { Married } \\
\end{array}$} & 245 & \multirow{2}{*}{$\begin{array}{l}67,7 \\
32,3\end{array}$} & $46+$ & 28 & 7,7 \\
\hline & 117 & & & 7 & \\
\hline
\end{tabular}

\subsection{Reliability and Validity}

In order to test the reliability of measurement tools, the Cronbach Alpha Coefficient (a) method, developed by Cronbach (1951), which is the most widely used statistical method and evaluates the internal consistency of the scale, was preferred. Cronbach's Alpha coefficient was calculated as,900 for the entire organisational climate scale, 0,937 for the entire affective commitment scale and 0,910 for the full job satisfaction scale. These values also show that the reliability of the scales is high (İslamoğlu and Alnıaçık, 2006, p.191). Although there are different validity techniques, construct validity has been used in this study. Explanatory factor analysis was applied to measure the construct validity. Kaiser-Meyer-Olkin (KMO) test and Bartlett's Test of Sphericity were conducted to demonstrate the suitability of the data for factor analysis. In factor analysis, the correlation coefficients between items are not harmful and are more significant than 0.250 were emphasised, on the other hand, it was predicted that those of which the common variance is below 0.50, the factor load is less than 0.50 , and the factor load is included in more than one dimension. The difference is lower than 0.10 should be excluded from the scale (Çokluk, Şekercioğlu, and Büyüköztürk, 2012: 206). The suitability of the data of all 
three scales to factor analysis was examined with the KMO sampling adequacy and the Barlett sphericity test. KMO values and Bartlett test results for all three scales were also found to be statistically significant $(\mathrm{p}<0.0001)$. Looking at the test results, it was determined that factor analysis was appropriate for the data on organisational climate, affective commitment and job satisfaction scales.

As a result of the first-factor analysis performed for the organisational climate scale, the items 21,15 and 10 were excluded from the scale because 21 and 15 were overlapping and the factor load of 10 was below 0.50 . As a result of the factor analysis continued with 27 items, it was seen that the organisational climate scale was gathered under 6 factors. As seen in Table 2, the first factor consisting of 6 items explains $16,914 \%$, the second explains $13,381 \%$, the third explains $10,917 \%$, the fourth explains $10,191 \%$, the fifth explains $6,712 \%$, and the sixth explains $6,662 \%$ of the total variance. Therefore, the total variance explained by the 6 factors was $64,777 \%$. When the items collected under the factors were examined, it was seen that the first factor was related to organisational structure, the second was related to rewarding, the third was related to support, the fourth was related to the moderate work environment, the fifth was related to risk-taking, and the sixth was related to individual responsibility, so the factors were named in this way.

Table 2. Organisational Climate Scale Factor Analysis

\begin{tabular}{|l|c|c|c|c|}
\hline \multicolumn{1}{|c|}{ Factors and Items } & Eigenvalue & $\begin{array}{c}\text { Explained } \\
\text { Variance } \\
\%\end{array}$ & Mean & Reliability \\
\hline I. Organizational Structure (Items 1,2,3,4,5,6 and 7) & 4,567 & 16,914 & 3,3208 &, 877 \\
\hline II. Rewarding (Items 12,13,14,16 and 17) & 3,613 & 13,381 & 3,1611 &, 872 \\
\hline III. Support (Items 26,27,28,29 and 30) & 2,948 & 10,917 & 3,6790 &, 814 \\
\hline IV. Moderate Work Environment (Items 22,23,24 and 25) & 2,752 & 10,191 & 3,2505 &, 784 \\
\hline V. Risk taking (Items 18,19 and 20) & 1,812 & 6,712 & 3,3591 &, 641 \\
\hline VI. Individual Responsibility (Items 8,9 and 11) & 1,799 & 6,662 & 3,7370 &, 586 \\
\hline \multicolumn{2}{|c|}{ Kaiser-Meyer-Olkin Sampling Adequacy: 90,3\% } \\
\hline
\end{tabular}

Cronbach Alpha values were used in the calculation of the organisational climate of the factors found as a result of factor analysis. These values are 0,877 for the organisational structure dimension, 0,872 for the rewarding dimension, 0,814 for 
the support dimension, 0,784 for the moderate work environment dimension, 0,641 for the risk-taking dimension and 0,586 for the individual responsibility dimension.

As a result of the factor analysis of the affective commitment scale, there was no need to remove any item from the scale, and it was observed that the affective organisational commitment scale was gathered under a single factor. As can be seen in Table 3, the affective commitment factor consisting of 6 items explains $76,326 \%$ of the total variance.

Table 3. Factor Analyzes of Affective Commitment and Job Satisfaction Scales

\begin{tabular}{|c|c|c|c|c|}
\hline \multirow{2}{*}{ Affective Commitment (6 items) } & Eigenvalue & $\begin{array}{c}\text { Explained } \\
\text { Variance \% }\end{array}$ & Mean & Reliability \\
\hline & 4,580 & 76,326 & 3,6878 & ,937 \\
\hline \multicolumn{5}{|c|}{$\begin{array}{c}\text { Kaiser-Meyer-Olkin Sampling Adequacy: } 88,6 \% \\
\text { Chi-Square for Bartlett's Test of Sphericity: } 2053,885 ; \mathrm{p}<0.0001 \\
\text { The total variance explained: .64,777\%; Reliability coefficient for the entire scale: } 0.937\end{array}$} \\
\hline \multirow[t]{2}{*}{ Job Satisfaction (9 items) } & Eigenvalu & $\begin{array}{c}\text { Explained } \\
\text { Variance \% }\end{array}$ & Mean & \multirow{2}{*}{$\begin{array}{c}\text { Reliability } \\
919\end{array}$} \\
\hline & 5,544 & 61,598 & 3,6286 & \\
\hline \multicolumn{5}{|c|}{$\begin{array}{c}\text { Kaiser-Meyer-Olkin Sampling Adequacy: } 92,5 \% \\
\text { Chi-Square for Bartlett's Test of Sphericity: } 1867,229 ; \mathrm{p}<0.0001 \\
\text { The total variance explained: .64,777\%; Reliability coefficient for the entire scale: } 0.919 \\
\end{array}$} \\
\hline
\end{tabular}

As a result of the factor analysis of the job satisfaction scale, there was no need to remove any item from the scale, and it was observed that the job satisfaction scale was gathered under a single factor. As seen in Table 3, the job satisfaction scale factor, which consists of 9 items, explains $61,598 \%$ of the total variance.

\subsection{Correlation Analysis Between Variables}

Correlation analysis was conducted to examine the relationship between the variables and their sub-dimensions within the scope of the study, and the analysis results are given in Table 4. 
Table 4. Correlation Analysis Between Variables

\begin{tabular}{|c|c|c|c|c|c|c|c|c|c|}
\hline Variables & OC & OS & IR & $\mathrm{R}$ & RT & WE & $S$ & $\mathrm{AC}$ & JS \\
\hline Organizational Climate & 1 & $891^{* *}$ & $154^{* *}$ &, $801^{* *}$ &, $589^{* *}$ & $430^{\star *}$ & $805^{\star *}$ & ,661 &, $766^{* *}$ \\
\hline $\begin{array}{l}\text { Organisational } \\
\text { Structure }\end{array}$ & & 1 &, 044 & ,619** & $476^{* *}$ &, $298^{* *}$ &, $678^{* *}$ &, $604^{* *}$ &, $716^{* *}$ \\
\hline $\begin{array}{l}\text { Individual } \\
\text { Responsibility }\end{array}$ & & & 1 & ,093 &, $177^{* *}$ &,$- 376^{* *}$ & ,076 & 080 &, $143^{* *}$ \\
\hline Rewarding & & & & 1 & ,340 &, $273^{* *}$ &, $596^{* *}$ &, $577^{* *}$ & ,638** \\
\hline Risk-Taking & & & & & 1 & 018 & $407^{* \star}$ & ,281** & $437^{* *}$ \\
\hline Work Environment & & & & & & 1 &, $185^{\star *}$ & $272^{* *}$ & $248^{* *}$ \\
\hline Support & & & & & & & 1 &, $569^{* *}$ & ,619** \\
\hline Affective Commitment & & & & & & & & 1 &, $715^{* *}$ \\
\hline Job Satisfaction & & & & & & & & & 1 \\
\hline
\end{tabular}

When the relationship between the sub-dimensions of organizational climate and affective commitment is examined, it was seen that there are positive and significant relationships between affective commitment and organizational climate ( $\mathrm{r}$ $=0.661, \mathrm{p}<0.01)$, organizational structure $(\mathrm{r}=0.604, \mathrm{p}<0.01)$, rewarding $(\mathrm{r}=0.577, \mathrm{p}$ $<0.01)$, risk taking $(\mathrm{r}=, 281, \mathrm{p}<0.01)$, work environment $(\mathrm{r}=0.272, \mathrm{p}<0.01)$ and support $(r=, 569, p<0.01)$, while there is no significant relationship between affective commitment and individual responsibility $(r=0.080, p>0.05)$. On the other hand, when the relationship between the sub-dimensions of organizational climate and job satisfaction is examined, it was seen that there are positive and significant relationships between job satisfaction and organizational climate $(r=0.766, p<0.01)$, organizational structure $(r=0.716, p<0.01)$, rewarding $(r=0.638, p<0.01)$, individual responsibility $(\mathrm{r}=0.143, \mathrm{p}<0.01)$, risk taking $(\mathrm{r}=0.437, \mathrm{p}<0.01)$, work environment $(\mathrm{r}=0.248, \mathrm{p}<0.01)$, and support $(\mathrm{r}=0.619, \mathrm{p}<0.01)$.

\subsection{Regression Analysis}

As found in the correlation analysis, significant relationships were found between organisational climate, its sub-dimensions and the variables of affective commitment and job satisfaction. After this stage, multiple linear regression analyses were conducted to reveal the effect levels of the variables on each other and to test the hypotheses produced within the scope of the research. 


\section{The Effect of Organizational Climate on the Affective Commitment}

Organisational structure, rewarding, individual responsibility, risk-taking, work environment and support variables, which are the sub-dimensions of organisational climate, were taken as the independent, and affective commitment was taken as the dependent variable, and multiple linear regression analysis was performed. $\mathrm{H}_{1}, \mathrm{H}_{1 \mathrm{a}}, \mathrm{H}_{1 \mathrm{~b}}, \mathrm{H}_{1 \mathrm{c}}, \mathrm{H}_{1 \mathrm{~d}}, \mathrm{H}_{1 \mathrm{e}}$ and $\mathrm{H}_{1 \mathrm{f}}$ hypotheses were tested with the regression analysis. The findings obtained from the analysis are summarised in Table 5.

Table 5. The Effect of Organizational Climate on the Affective Commitment

\begin{tabular}{|c|c|c|c|c|c|c|c|}
\hline & \multicolumn{2}{|c|}{$\begin{array}{l}\text { Non-Standardized } \\
\text { Coefficients }\end{array}$} & \begin{tabular}{|c|} 
Standardized \\
Coefficients \\
\end{tabular} & $t$ & \multirow{2}{*}{$\mathrm{p}$} & \multirow{3}{*}{ Tolerance } & \multirow{3}{*}{ VIF } \\
\hline & $\mathrm{B}$ & Std. Error & Beta & & & & \\
\hline Constant &,- 058 & ,296 & &,- 197 & 844 & & \\
\hline $\begin{array}{c}\text { Organizational } \\
\text { Structure }\end{array}$ & ,333 & ,070 &, 287 & 4,760 &, 000 & 414 & 2,416 \\
\hline $\begin{array}{c}\text { Individual } \\
\text { Responsibility }\end{array}$ & ,094 & ,053 & ,077 & 1,770 & ,078 & 803 & 1,246 \\
\hline Rewarding & ,290 & ,062 & ,246 & 4,654 & , 000 & ,539 & 1,855 \\
\hline Risk Taking &,- 049 &, 049 &,- 045 &,- 989 & ,323 & 732 & 1,366 \\
\hline $\begin{array}{c}\text { Work } \\
\text { Environment }\end{array}$ & 111 & ,047 & ,108 & 2,383 & ,018 & ,731 & 1,369 \\
\hline Support & ,284 &, 072 & ,220 & 3,933 & , 000 & 482 & 2,074 \\
\hline
\end{tabular}

When the multiple linear regression analysis results are examined, it is seen that the model is significant $(F=51,219 ; p=0,0001)$. VIF values were found as the lowest 1.246 and the highest at 2,416, and it can be said that there is no multiconnection problem (VIF> 10). In addition, the D-W value was found to be 1,820 . This finding indicates that there is no autocorrelation. When the model is examined, it can be said that the organisational climate affects affective commitment. There is a positive relationship between organisational climate and affective commitment $(R=$ 0.776). The ratio of organisational climate to explain the dependent variable, affective commitment, was found to be $\mathrm{R}^{2}=0.663$. This result shows that $66,3 \%$ of the affective commitment variable can be explained by the organisational climate. In this sense, according to the results of simple linear regression analysis, $\mathrm{H}_{1}$ hypothesis was 
accepted. In addition, when the model was examined, organisational structure, reward, work environment and support dimensions, which are among the subdimensions of the organisational climate scale, were found to be statistically significant. In this sense, it can be said that organisational structure, rewarding, work environment and support dimensions affect affective commitment. This result shows that $33,3 \%$ of the change in affective commitment can be explained by organisational structure, $29 \%$ by rewarding, $11,1 \%$ by the work environment and $28,4 \%$ by support dimension. According to the results of multiple linear regression analysis made in this sense, $\mathrm{H}_{1 \mathrm{a}}, \mathrm{H}_{1 c}, \mathrm{H}_{1 \mathrm{e}}$ and $\mathrm{H}_{1 \mathrm{f}}$ hypotheses were accepted while $\mathrm{H}_{1 \mathrm{~b}}$ and $\mathrm{H}_{1 \mathrm{~d}}$ were rejected.

\section{The Effect of Organizational Climate on Job Satisfaction}

Organisational structure, rewarding, individual responsibility, risk-taking, work environment, support variables, which are sub-dimensions of organisational climate, were taken as the independent, and job satisfaction was taken as the dependent variable, and multiple linear regression analysis was performed. With the regression analysis, $\mathrm{H}_{2}, \mathrm{H}_{2 \mathrm{a}}, \mathrm{H}_{2 \mathrm{~b}}, \mathrm{H}_{2 \mathrm{c}}, \mathrm{H}_{2 \mathrm{~d}}, \mathrm{H}_{2 \mathrm{e}}$ and $\mathrm{H}_{2 \mathrm{f}}$ hypotheses were tested. The findings obtained from the analysis are summarised in Table 6.

When the results of multiple linear regression analysis are examined, it is seen that the model is significant $(F=89.724 ; p=0.0001)$. VIF values were found as the lowest 1.246 and the highest at 2.416, so it can be said that there is no multiconnection problem (VIF> 10). Besides, the D-W value was found to be 1.723 . This finding indicates that there is no autocorrelation. 
Table 6. The Effect of Organizational Climate on Job Satisfaction

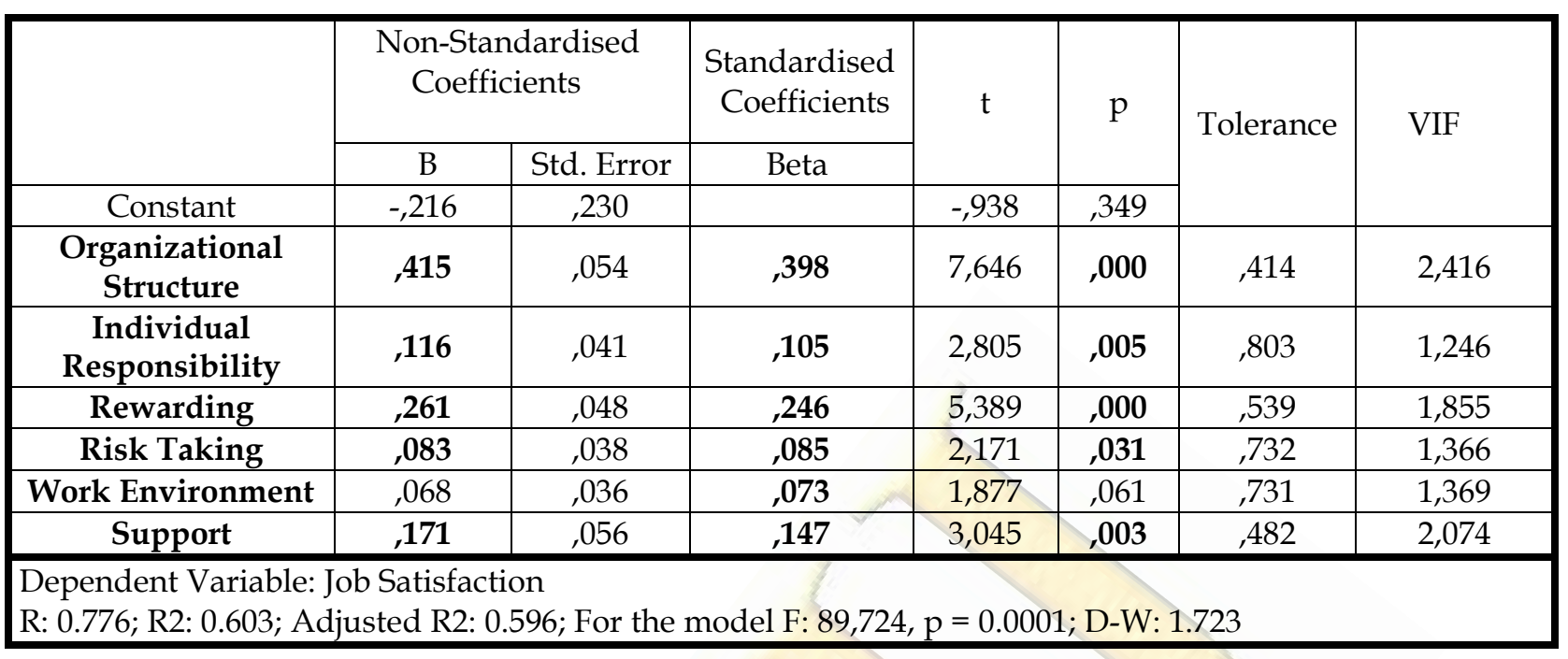

When the model is examined, it can be said that the organisational climate affects job satisfaction. There is a positive relationship between organisational climate and job satisfaction $(R=0.776)$. The ratio of organisational climate to explain job satisfaction, which is the dependent variable, was found to be $R^{2}=0.603$. This result shows that the organisational climate can explain $60,3 \%$ of job satisfaction change. In this sense, according to the simple linear regression analysis results, $\mathrm{H}_{2}$ hypothesis was accepted. In addition, when the model was examined, organisational structure, rewarding, risk-taking, individual responsibility and support dimensions, which are among the sub-dimensions of the organisational climate scale, were found to be statistically significant. In this sense, it can be said that organisational structure, rewarding, work environment and support dimensions affect job satisfaction. This result shows that $41,5 \%$ of the change in job satisfaction can be explained by organisational structure, $11,6 \%$ by the individual responsibility, $26,1 \%$ by rewarding, $8,3 \%$ by risk-taking, $17,1 \%$ by support dimension. According to the results of multiple linear regression analysis made in this sense, $\mathrm{H}_{2 \mathrm{a}}, \mathrm{H}_{2 b}, \mathrm{H}_{2 c}, \mathrm{H}_{2 \mathrm{~d}}$ and $\mathrm{H}_{2 \mathrm{f}}$ hypotheses were accepted, and $\mathrm{H}_{2 \mathrm{e}}$ hypothesis was rejected.

\section{RESULTS AND RECOMMENDATIONS}

Within the scope of the research, it was aimed to investigate the effect of organisational climate on the affective organisational commitment and job 
satisfaction of the employees in hotel enterprises, which are labour-intensive organisations. For this purpose, the data obtained from the questionnaires applied to the participants were subjected to the necessary analysis. The organizational climate $(\alpha=0.892)$, affective commitment $(\alpha=0.937)$ and job satisfaction $(\alpha=0.919)$ scales used in the study were found to be reliable in measuring the relevant variables.

According to the result of the factor analysis applied to the organisational climate scale, it was observed, parallel to the original scale, that the scale was factored into six dimensions: organisational structure, rewarding, support, moderate work environment, risk-taking and individual responsibility. When the arithmetic mean of the dimensions was examined, it was found to be 3,32 for the organisational structure dimension, 3,16 for the rewarding dimension, 2,67 for the support dimension, 3,25 for the moderate work environment dimension, 3,35 for the risktaking dimension and 3,75 for the individual responsibility dimension. When the sub-dimensions of organisational climate are examined, it was determined that all dimensions are above the relative mean, and individual responsibility is the most perceived dimension by the participants with an average of 3,75 . In addition, as a result of the factor analysis applied to the affective commitment and job satisfaction scales, it was determined that the scales preserve their unidimensional structure and the arithmetic mean of the affective commitment level of the employees was 3,68. The arithmetic mean of their job satisfaction level was 3,62. According to these findings, it can be said that employees generally have a positive perception of organisational climate in their hotels and exhibit an attitude at the level of participation for affective commitment and job satisfaction. Considering that positive organisational climate, affective commitment and job satisfaction affect many behaviours that are desired to be seen in the organisation in a positive and the behaviours that are not desired to be seen negatively, this result can be evaluated as a favourable situation for hotel enterprises that form the research field.

As a result of this study, it was seen that positive organisational climate positively affected the affective organisational commitment and job satisfaction of the employees. These findings of the study coincide with the results of Tyagi and Wotruba (1993), Özdevecioğlu (2003), Parker et al. (2003), Halis and Uğurlu (2008), 
James et al. (2008), Çekmecelioğlu (2011) and Dorgham (2012) 's studies that investigate the effect of organisational climate on the affective commitment and Mahajan et al. (1984), Putti and Kheun (1986), Gratto (2001), Topçu (2006), Castro (2008), Özsoy (2012), Erdoğan (2013) and Sönmez (2014) 's studies that investigate the effect of organisational climate on the job satisfaction. Also, in the study findings, it was observed that organisational structure, rewarding, moderate work environment and support dimensions increase the organisational commitment of the employees, and the organisational structure, individual responsibility, reward and support dimensions similarly increase the satisfaction levels of the employees with their jobs.

The study revealed that the organisational climate plays a vital role in employees' affective commitment and job satisfaction. Based on this finding of the study and the literature, some suggestions were made to practitioners and researchers who are interested in the subject and want to examine it.

Tourism enterprises are labour-intensive enterprises, where the human factor is essential. Therefore, excellent and efficient management of human resources is the key to the success of the organisation. In this sense, the factors that affect the performance and success of employees should be scrutinized. Both concepts of affective organisational commitment and job satisfaction are the leading factors. For this reason, keeping the commitment and job satisfaction levels of the employees high will increase the level of organisational behaviours desired in the organisation and decrease the undesirable ones. In this context, it is an indispensable factor for hotel enterprises that want to exist in today's dynamic and changing competitive environment to make the necessary effort to create a positive organisational climate to continue their success. In order to create a positive organisational climate in the organisation, a flexible organisational structure can be provided, employees can be encouraged to take individual responsibility, fair and objective rewarding systems can be established, and employees can be allowed to take risks. However, they should be made to feel that they will not be punished in possible negative situations due to the risks they will take, and they should not be discouraged by a feeling of insecurity. In the organisation, practices that will create friendly environments both in relations between employees and between managers and subordinates can be 
implemented, and an environment where employees are supported by each other and their managers can be created. However, while doing these, it should not be forgotten that control and communication mechanisms must be provided well without departing from organisational goals. In addition, hotel HR departments should measure employees' perceptions of organisational climate at certain time intervals. They should identify possible obstacles to employees' perceptions of positive organisational climate and take the necessary measures to eliminate them.

This study was carried out in a certain period of time within the scope of some hotel enterprises. Therefore, the findings should be supported by researches to be conducted on the subject in different samples and time periods. In this sense, it is suggested to researchers who are interested in the subject that future studies on the same variables should be carried out in different samples and periods in the same sector and different sectors both.

In addition, it is thought that researching the variables by associating them with different organisational and individual variables will make a contribution and bring depth to the relevant literature. For example, variables such as leadership, performance, mobbing, organisational silence, nepotism, cynicism, productivity, absenteeism, and other variables such as emotional intelligence, positive affect, alienation and life satisfaction are suggested as some of these. 


\section{REFERENCES}

Ada, N., Alver, İ., and Atlı, F. (2008). Örgütsel iletişimin örgütsel bağlllık üzerine etkisi: Manisa Organize Sanayi Bölgesi'nde yer alan ve imalat sektörü çalışanları üzerinde yapılan bir araştırma. Ege Akademik Bakış Dergisi, 487-518.

Ağaoğlu, O.K. (1992). İsgücünü verimli kullanma tekniklerinin turizm sektörüne uygulanması. Yayın No:457: Ankara: Milli Prodüktivite Yayınları.

Akdemir, A. (2017). Otel işletmelerinde örgüt iklimine etki eden yönetsel güç kaynaklarımın belirlenmesi. Yüksek Lisans Tezi. Nevşehir Hacı Bektaş Veli Üniversitesi Sosyal Bilimler Enstitüsü, Nevşehir.

Allen, N. J., and Meyer, J. P. (1990). Organisational commitment: Evidence of career stage effects. Journal of Business Research, 46-91.

Amabile, T. M., Conti, R., Coon, H., Lazenby, J., and Herron, M. (1996). Assessing the work environment for creativity. Academey of Management Journal, 11541184.

Arslan, Y. (2009). Kurumsallaşma ve örgütsel güven ilişkisi. Yayınlanmamış Yüksek Lisans Tezi. Gebze İleri Teknoloji Enstitüsü.

Atkinson, T. and Frechette, H. 2009. Creating a positive organisational climate in a negative economic on improving organisational climate to transform performance. Forum Transforming Performance

Baş, T., Amarat, M., Ünal, Ö., Durmuş, A., and Boz, Ş. (2018). Örgütsel iklimin örgütsel bağlllı̆̆a etkisi: Özel hastane örneği. Mehmet Akif Ersoy Üniversitesi İktisadi ve İdari Bilimler Fakültesi Dergisi, 538-548.

Başaran, İ. (1992). Yönetimde insan ilişkileri: Yönetsel davranış. Ankara: Gül Yayınları.

Benson, J. (1996). Dual commitment: Contract workers in Australian manufacturing enterprises (Working Paper 101). Melbourne: University of Melbourne.

Bilir, P. (2005). Gençlik ve Spor Genel Müdürlüğ̈̈nün örgüt iklimi ve çalışanların katılımla ilgili algılamaları. Doktora Tezi. Çukurova Üniversitesi. Adana.

Bolat, O. İ., and Bolat, T. (2008). Otel işletmelerinde örgütsel bağlll1k ve örgütsel vatandaşlık davranışı ilişkisi. Balıkesir Üniversitesi Sosyal Bilimler Enstitüsü Dergisi, 75-94.

Castro, M. L. (2008). The relationship between organisational climate and employee satisfaction in South African information and technology organisation. University of South Africa.

Cronbach, L. J., (1951). Coefficient alpha and the internal structure of tests. Psychometrika (16), 297-334.

Çekmecelioğlu, G. H. (2006). İş tatmini ve örgütsel bağlllık tutumlarının işten ayrılma niyeti ve verimlilik üzerindeki etkilerinin değerlendirilmesi: Bir araştırma. İş, Güç, Endüstri İlişkileri ve İnsan Kaynaklarn Dergisi, 153-168.

Çekmecelioğlu, H., and Günsel, A. (2011). Rol stresi kaynaklarının iş tutumları açısından değerlendirilmesi: Kimya sektöründe bir uygulama. Organizasyon ve Yönetim Bilimleri Dergisi, 33-43. 
Çokluk, Ö., Şekercioğlu, G., and Büyüköztürk, Ş. (2012). Sosyal bilimler için çok değişkenli istatistik, SPSS uygulamaları. Ankara: Pegem Akademi.

De Clercq, D., and Belausteguigoitia Rius, I. (2007). Organisational commitment in Mexican small and medium-sized firms: The role of work status, organisational climate, and entrepreneurial orientation. Journal of Small Business Management, 45(4), 467-490.

Demir, H., Usta, R., and Okan, T. (2008). İçsel pazarlamanın örgütsel bağlllık ve iş tatminine etkisi. HÜ İktisadi ve İdari Bilimler Fakültesi Dergisi, 135-161.

Dorgham, S. R. (2012). Relationship between organisation work climate and staff nurses organisational commitment. Nature and Science, 10 (5), 80-91.

Erdoğan, Ş. (2013). Örgüt iklimi ile çalışanlarn motivasyonu ve iş tatmini arasındaki ilişkiler: Özel hastanede bir uygulama. Yüksek Lisans Tezi. İzmir Gediz Üniversitesi Sosyal Bilimler Enstitüsü.

Gerçeker, B (2012). Sağlık Kuruluşlarında Örgüt İklimi ve Bilgi Güvenliğinin İlişkisi. Yüksek Lisans Tezi. Dokuz Eylül Üniversitesi Sağlık Bilimleri Enstitüsü, İzmir

Gratto, F. J. (2001). The relationship between organisational climate and job satisfaction for directors of physical plants. Unpublished Ph.D., University of Florida, United States -- Florida.

Gündoğan, T. (2009). Örgütsel bağlllk: Türkiye Cumhuriyeti Merkez Bankası uygulaması. Yayınlanmamış Yeterlilik Tezi. Türkiye Cumhuriyet Merkez Bankası İnsan Kaynakları Genel Müdürlüğü: Ankara

Güney, S. (2012). Liderlik. Ankara: Nobel Akademik Yayınları.

Halis, M., and Uğurlu, Ö. (2008). Güncel çalışmalar 1şığında örgüt iklimi. İş, Güç, Endüstri İlişkileri ve İnsan Kaynaklarn Dergisi, 103 (2), 103.

Hassan, S., and Rohrbaugh, J. (2012). Variability in the organisational climate of government offices and affective organisational commitment. Public Management Review, 14 (5), 563-584.

Hemingway, M. A., and Smith, C. S. (1999). Organisational climate and occupational stressors as predictors of withdrawal behaviors and injuries in nurses. Journal of Occupational and Organisational Psychology, 285-299.

Hocaniyazov, A. (2008). Ağırlama işletmelerinde örgütsel iklim ve liderlik. Yüksek Lisans Tezi. Dokuz Eylül Üniversitesi. İzmir.

Hughes, L. W., Avey, J. B., and Norman, S. M. (2008). A study of supportive climate, trust, engagement and organisational commitment. Journal of Business and Leadership: Research, Practice, and Teaching , 4(2), 51-59.

İslamoğlu, H., and Alnıaçık, Ü. (2011). Sosyal bilimlerde araştırma yöntemleri. İstanbul: Beta Yayınları.

Keleş, Ö. (2008). Örgüt iklimi boyutlarmın çalışanlarn güçlendirme algılarıyla ilişkilerinin değerlendirilmesi: Bir araştırma. Yüksek Lisans Tezi. Kocaeli

Üniversitesi. 
Köse, S., Kartal, B., and Kayalı, N. (2003). Örgütsel vatandaşlık davranışı ve tutuma ilişkin faktörlerle ilişkisi üzerine bir araştırma. Erciyes Üniversitesi İktisadi İdari Bilimler Fakültesi Dergisi, 1-19.

Leonard, D., and Swap, W. (2005). Kıvılcımlar uçuşurken. İstanbul: Optimist Yayınları.

Litwin, G., and Stringer, R. (1968). Motivation and organisational climate. Boston: Harvard University Press.

Locke, E. A. (1969). What is job satisfaction. Organisational Behavior and Human Performance, 309-336.

Mahajan, J., Churchill, G. A., Ford, N. M., and Walker, O. C. (1984). A comparison of the impact of organisational climate on the job satisfaction of manufacturers' agents and company salespeople: An exploratory study. Journal of Personal Selling and Sales Management, 1-10.

Mathieu, J. E., and Zajac, D. M. (1990). A review and meta-analysis of the antecedents, correlates, and consequences of organisational commitment. Psychological Bulletin, 108(2), 171-194.

Mercan, N. (2007). Örgütlerde mobbing'in örgüt iklimiyle ilişkisine yönelik bir araştırma. Yüksek Lisans Tezi. Dumlupınar Üniversitesi. Kütahya.

Meyer, J. P., and Allen, N. J. (1991). A three-component conceptualisation of organisational commitment. Human Resource Management Review, 1 (1), 6189.

Meyer, J. P., Allen, N. J., and Smith, C. A. (1993). Commitment to organisations and occupations: Extention and test of a three-component conceptualisation. Journal of Applied Psychology, 538-551.

Moran, E. T., and Volkwein, J. F. (1992). The cultural approach to the formation of organisational climate. Human Relations, 19-47.

Mowday, R. T., Porter, L. W., and Steers, R. M. (1979). The measurement of organisational commitment. Journal of Vocational Behavior, 224-247.

Mowday, R. T., Porter, L. W., and Steers, R. M. (1982). Employee-organisation linkages: The psychology of commitment, absenteeism, and turnover. New York: Academic Press.

Oktay, E., and Gül, H. (2003). Çalışanların duygusal bağhllıklarının sağlanmasında Conger lider özelliklerinin etkileri üzerine Karaman ve Aksaray emniyet müdürlüklerinde yapılan bir araştırma. Selçuk Üniversitesi Sosyal Bilimler Enstitüsü Dergisi, 403-428.

Özdemir, F. (2006). Örgütsel iklimin iş tatmini düzeyine etkisi: Tekstil sektöründe bir araştırma. Yayınlanmamış Doktora Tezi. Çukurova Üniversitesi SBE. Adana.

Özdevecioğlu, M. (2003). Algılanan örgütsel destek ile örgütsel bağlllık arasındaki ilişkilerin belirlenmesine yönelik bir araştırma. D.E.Ü.I.I.̇.B.F. Dergisi, 18 (2), 113-130.

Özsoy, İ. (2012). İklimin, öz liderlik ve iş tatmininin ar-ge performansina etkisi: Savunma sanayinde bir araştırma. Doktora Tezi. Kara Harp Okulu Savunma Bilimleri Enstitüsü. Ankara. 
Parker, C. P., Baltes, B. B., Young, S. A., and Huff, J. W. (2003). Relationships between psychological climate perceptions and work outcomes: A meta-analytic review. 24, 389-416.

Pati, G. and Reilly, C. W. (1977). Reversing discrimination: a perspective. Human Resource Management, 16(4), 25.

Porter, L. W., Steers, R. M., Mowday, R. T., and Boulian, P. V. (1974). Organisational commitment, job satisfaction and turnover among psychiatry technicians. Journal of Applied Psychology, 603-609.

Pritchard, R. D., and Karasick, B. W. (1973). The effects of organisational climate on managerial job performance and job satisfaction. Organisational Behavior and Human Performance, 126-146.

Putti, J. M. and Kheun, L. S. (1986). Organisational climate -job Satisfaction relationship in a public sector organisation. International Journal of Public Administration, 8(3), 337.

Riad, L., Labib, A., \& Nawar, Y. S. (2016). Assessing the impact of organisational climate on employees. The Business of Management Review, 7, 357-364.

Rusu, G., and Avasilca, S. (2014). Linking human resources motivation to organisational climate. Procedia - Social And Behavioral Sciences, 124 (1), 51-58.

Ruth, M. G. (1992). Organisational climate and communication climate. Predictors of commitment to the organisation. Management Communication Quarterly: McQ (1986-1998), 5(4), 379.

Schnedder, B., and Snyder, R. (1975). Some relationships between job satisfaction and organisational climate. Journal of Applied Psychology, 318-328.

Schneider, S. H. (1996). The future of climate: Potential for interaction and surprises' in, downing, T.E. (ed.), Springer-Verlag, 137, 77-113. Climate Change and World Food Security, 77-113.

Shalley, C., Gilson, L., and Blum, T. (2000, April). Matching creativity requirements and the work environment: Effects on satisfaction and intentions to leave. Academy of Management Journal, 215-223.

Sönmez, H. (2014). Değişim yaşanan örgütlerde iş tatmini ile örgütsel bă̆lllık ilişkisi. Yüksek Lisans Tezi. Ege Üniversitesi SBE. İzmir.

Spreitzer, G. M. (1996). Social structural characteristics of psychological empowerment. Academy of Management Journal, 483-504.

Steers, R. M. (1977). Antecedents and outcomes of organisational commitment. Administrative Science Quarterly 22, 46-56.

Stringer, R. (2002). Leadership and organisational climate. New Jersey, U.S.A.:

Prentice Hall.

Şener, Y. (2017). Örgüt ikliminin iş performansı üzerindeki etkisinde psikolojik sermayenin ara değişken rolü. Yüksek Lisans Tezi. İstanbul Kültür Üniversitesi.

Tagiuri, R. (1968). The concept of organizational climate. In R. Tagiuri, and H. Litwin (Eds.), Organisational Climate: Explorations of a Concept. Division of 
Research Graduate School of Business Administration, 11-32. Printed United States of America.

Topçu, D. (2006). İnsan kaynakları uygulamaları, örgüt iklimi ve iş tatmini arasındaki ilişkiler: Bankacılık sektöründe bir uygulama. Gebze İleri Teknoloji Enstitüsü.

Tyagi, P. K., and Wotruba, W. R. (1993). An exploratory study of reverse causality relationships among sales force. Journal of the Academy of Marketing Science, 143-153.

Uyguç, N., and Çımrın, D. (2000). DEÜ Araştırma ve Uygulama Hastanesi laboratuarı çalışanlarının örgüte bağlılıklarını ve işten ayrılma niyetlerini etkileyen faktörler. Dokuz Eylül Üniversitesi İ.İ.B.F. Dergisi, 91-99.

Wallace, J., Hunt, J., and Richards, C. (1996). The relationship between organisational culture, organisational climate and managerial values: A proposed model. Paper presented at the ANZAM 96 Diversity and Change, University of Wollongong.

Wasti, S. A. (2000). Meyer ve Allen'in üç boyutlu örgütsel bağlılık ölçeğinin geçerlik ve güvenirlik analizi. 8. Ulusal Yönetim ve Organizasyon Kongresi Bildiriler Kitabı, 401 -410.

Yalçın, A., and İplik, F. N. (2005). Beş yıldızlı otellerde çalışanların demografik özellikleri ile örgütsel bağlılıkları arasındaki ilişkiyi belirlemeye yönelik bir araştırma: Adana ili örneği. Çukurova Üniversitesi Sosyal Bilimler Enstitüsü Dergisi, 4 (1), 395-412.

Yüceler, A. (2005). Örgütsel bağhllk ve örgüt iklimi ilişkisi: Teorik ve uygulamalı bir çalışma. Yüksek Lisans Tezi. Selçuk Üniversitesi Sosyal Bilimler Enstitüsü. Konya.

Zammuto, R. F., and Krakower, J. Y. (1991). Quantitative and qualitative studies of organisational culture. JAI Press Inc.

Zeybek, K. (2010). Hastane işletmelerinde örgüt iklimi ve tükenmişlik etkileşimi. Yüksek Lisans Tezi. Dokuz Eylül Üniversitesi. İzmir. 